\title{
Protecting Children by Healing Their Caregivers
}

\author{
Annie Laurie Gula, MD
}

Division of General Pediatrics, Children's Hospital of Philadelphia, Philadelphia, Pennsylvania.

t was a busy night in the emergency department. EMS called to give a heads up-they were on their way with a girl who was "pretty banged up." They warned us that the story seemed a little fishy. We thought we were ready. The trauma bay was organized; supplies were at the ready and everyone had a role. Within seconds of her arrival, it was clear that no one could ever have been truly prepared. She was unresponsive and unstable. Her injuries were widespread, brutal, and long term. My seasoned attendings would describe it as no less than horrific. There was no question-someone had done this to her.

After she was stabilized, her wounds were gently tended, her body was bathed, her hair was combed. She died several days later. While distressed, many members of her team took consolation in the idea that, after years of torture, she finally got to be loved.

It's no wonder that every person involved with her care during her hospitalization was so deeply affected by her. How could anyone do this to another person? Or even worse, to an innocent child? "What a monster," we said. "Only a monster could have done this."

While anyone would agree that what this abuser-the girl's mother-did was brutal and wrong, I would also argue that the underlying danger is much more systemic. We call her the "monster," but I sense that the real monster is still lurking in the shadows, unnamed. I can't help but try to understand this woman; it is unfair to condemn her without first learning her story. How were her actions guided by her own history of trauma, abuse, and violent discipline as a child? We preach to each other and to our learners that trauma-informed care is essential; you must not ask what's wrong with you, but what happened to you. Founder and Director of the Equal Justice Initiative Bryan Stevenson has said that "each of us is more than the worst thing we've ever done." ${ }^{11}$ It's inhumane of us to dehumanize her for this atrocity, especially without pausing to ask how her environment, personal trauma, and understanding of child development set the risk.

It is important to understand the cycle of trauma and abuse. Traumatic experiences have been shown to alter neurodevelopment and the body's stress response, particularly when experiences take place early in life, when they are repeated and

Corresponding Author: Annie Laurie Gula, MD; Email: gulaa@email.chop.edu; Telephone: 412-841-7331; Twitter: @anniegula.

Published online first January 20, 2021

Received: May 22, 2020; Revised: July 19, 2020; Accepted: July 30, 2020

(C) 2021 Society of Hospital Medicine DOI 10.12788/jhm.3511 long term, and when they are severe. We know that adverse childhood experiences are cumulative and result in adverse outcomes as adults, including increased likelihood of violent or criminal activity. We know that prior history of trauma, specifically child abuse, sexual abuse, or domestic violence, is associated with higher potential for child abuse later on.

The effect of experiencing trauma is such that only $22 \%$ of adults who experienced abuse or neglect as children will achieve resiliency. ${ }^{2}$ In a world in which social distancing and isolation have become the new normal, we must be even more aware of the effects of trauma on families. The COVID-19 pandemic has increased known risk factors for child abuse, including financial hardship, unemployment, increased anxiety, increased caregiver responsibilities, and decreased access to mental health services and community resources. ${ }^{3}$ Furthermore, virtual learning environments may have significant implications on the reporting of child abuse. Among cases of maltreatment of children that received an investigation or alternative response in 2018, 20.5\% were reported by education personnel. ${ }^{4}$ While remote learning options may be necessary to minimize risk of viral spread, fewer interactions between children and mandatory reporters may result in child maltreatment going undetected. In the face of these challenges, I urge our healthcare system to use current constraints as fuel for creative interventions including the following:

- Applying advances in telemedicine to create a new opportunity to interface with families, provide mental health support, connect them with resources, and offer gentle guidance about safe parenting.

- Improving both screening methods for parental trauma and distress and referrals for support services.

- Advocating for adequate access to life-sustaining resources including shelter, food, and healthcare for all families. This is a necessary foundation for building resilience.

- Providing bias training for mandatory reporters to ensure that all children and their families are approached with respect and compassion.

- Prioritizing innovation that provides long-lasting, sustainable, and equitable access to support and healing.

To best protect our children, we must heal their adult caregivers; we must help them to conquer their monsters.

Our patient and her family have since visited me in my thoughts and dreams, less often now than before. While I never truly knew her, she has left an open void where there should have been the promise of a healthy, growing, and developing child. Within that void resides fear. I fear for other "hidden children" and the abuse they are at risk for experiencing. I fear 
that her siblings, now living without their mother, will become victims of the instability of being "in the system." I fear that by turning to punishment as our only solution, we miss opportunities to prevent such tragedy. Despite the darkness, she also brings me hope. I hope that her siblings can rely on each other as a foundation for resilience. I hope that we as a healthcare system can continue to love our patients without question or

\section{References}

1. Stevenson B. Just Mercy: A Story of Justice and Redemption. Spiegel \& Grau; 2015.

2. De Bellis MD, Zisk A. The biological effects of childhood trauma. Child Adolesc Psychiatr Clin N Am. 2014;23(2):185-222. https://doi.org/10.1016/j. chc.2014.01.002

3. Schneider W, Waldfogel J, Brooks-Gunn J. The Great Recession and risk for condition. I hope that we as a society can invest in breaking the cycle of trauma and in supporting parents. I hope that we can create a system in which children can grow up free from abuse.

Disclosures: Dr. Gula has no financial relationships relevant to this article or conflicts of interest to disclose.

child abuse and neglect. Child Youth Serv Rev. 2017;72:71-81. https://doi. org/10.1016/j.childyouth.2016.10.016

4. Child Maltreatment 2018. Children's Bureau, Youth and Families, Administration on Children, Administration for Children and Families, U.S. Department of Health \& Human Services; January 15, 2020. Accessed May 10, 2020. https://www.acf.hhs.gov/cb/resource/child-maltreatment-2018 